\title{
Insufficient Angiogenesis: Cause of Abnormally Thin Endometrium in Subfertile Patients?
}

\author{
Insuffiziente Angiogenese: Ursache eines abnorm dünnen \\ Endometriums bei subfertilen Patientinnen?
}

Authors

Joachim Alfer ${ }^{1}$, Lars Happel ${ }^{2}$, Ralf Dittrich ${ }^{3}$, Matthias W. Beckmann ${ }^{3}$, Arndt Hartmann ${ }^{4}$, Andreas Gaumann ${ }^{1}$, Volker U. Buck ${ }^{5}$, Irmgard Classen-Linke ${ }^{5}$

Affiliations

1 Institute of Pathology, Kaufbeuren-Ravensburg, Ravensburg, Germany

2 Institute of Reproductive Medicine, IVF-Saar, Saarbrücken, Germany

3 Department of Obstetrics and Gynecology, Erlangen University Hospital Friedrich-Alexander Universität, Erlangen-Nürnberg, Germany

4 Department of Pathology, Erlangen University Hospital Friedrich-Alexander Universität, Erlangen-Nürnberg, Germany

5 Institute of Molecular and Cellular Anatomy, Medical Faculty, RWTH Aachen University, Aachen, Germany

Key words

thin endometrium, IVF, LIF, VEGF, $\beta_{3}$ integrin, angiogenesis

Schlüsselwörter

dünne Gebärmutterschleimhaut, IVF, LIF, VEGF, $\beta_{3}$-Integrin, Angiogenese

received $\quad 13.4 .2017$

revised 21.5.2017

accepted 22.5.2017

Bibliography

DOI https://doi.org/10.1055/s-0043-111899

Geburtsh Frauenheilk 2017; 77: 756-764 @ Georg Thieme

Verlag KG Stuttgart · New York | ISSN 0016-5751

\section{Correspondence}

Dr. med. Joachim Alfer

Institute of Pathology, Kaufbeuren-Ravensburg

Elisabethenstraße 19, 88212 Ravensburg, Germany

joachim.alfer@pathologie-ravensburg.de

\section{ABSTRACT}

Introduction This study investigated subfertile patients with abnormally thin endometrium after infertility treatment. As they had adequate serum concentrations of hormones, an endometrial factor for subfertility was suspected.
Methods To elucidate the cause of subfertility, endometrial biopsies were taken in each patient in the late proliferative and mid-secretory phases of one menstrual cycle. Endometrial biopsies from women with normal menstrual cycles and confirmed fertility who were undergoing hysterectomy for benign uterine disease were used as positive controls. The tissue samples were investigated for steroid hormone receptor expression and for the proliferation marker Ki-67. Immunohistochemistry was performed with antibodies against the marker molecules for endometrial receptivity - $\beta_{3}$ integrin, VEGF, LIF, and CD56 (large granular lymphocytes, LGLs).

Results The steroid hormone receptors for estrogen (E2) and progesterone $(\mathrm{P})$ were expressed normally (at the first biopsy) and were down-regulated (at the second biopsy) within the cycle. Strikingly, all of the marker molecules investigated showed negative or weak and inadequate expression in the mid-secretory phase. Numbers of LGLs remained as low as in the proliferative phase. In contrast, fertile patients were found to express these marker molecules distinctly in the mid-secretory phase.

Conclusions It may be hypothesized that a severe deficiency of these angiogenesis-related marker molecules leads to defective development of the endometrium, which remains thin. Deficient angiogenetic development may thus provide an explanation for the endometrial factor that causes infertility. Further investigations will need to focus on identifying the regulating factors that act between steroid receptor activation and the expression of these marker molecules.

\section{ZUSAMMENFASSUNG}

Einleitung Diese Studie untersuchte subfertile Patientinnen mit einem abnorm dünnen Endometrium nach einer Infertilitätsbehandlung. Da ausreichende Hormonkonzentrationen im Blut dieser Frauen gemessen wurden, lag die Vermutung nahe, dass ein endometrialer Faktor für die verminderte Fertilität eine Rolle spielen könnte.

Methoden Um möglichen Ursachen für die verminderte Fertilität auf den Grund zu gehen, wurden bei jeder Patientin Biopsien des Endometriums in der späten Proliferationsphase sowie in der mittleren Sekretionsphase eines Menstruationszyklus durchgeführt. Endometriale Biopsien von fertilen Frau- 
en mit regulärem Menstruationszyklus, die sich einer Hysterektomie wegen gutartiger Gebärmutterveränderungen unterziehen mussten, dienten als Positivkontrollen. Die Gewebeproben wurden auf die Expression von Steroidhormonrezeptoren sowie mit dem Proliferationsmarker Ki-67untersucht. Mithilfe von Antikörpern gegen Markermoleküle der endometrialen Rezeptivität: $\beta 3$-Integrin, VEGF, LIF und CD56 (große granuläre Lymphozyten, LGLs), wurden immunhistochemische Untersuchungen durchgeführt.

Ergebnisse Die Steroidhormonrezeptoren für Östrogen (E2) und Progesteron $(P)$ waren bei der ersten in einem Zyklus durchgeführten Biopsie normal exprimiert und in der zweiten Biopsie im selben Zyklus herunterreguliert. Auffallend war, dass die Expression aller untersuchten Marker in der mittleren Sekre- tionsphase negativ oder schwach bzw. ungenügend war. Die Anzahl der LGLs blieb so niedrig wie in der Proliferationsphase. Dagegen wurden diese Markermoleküle bei fertilen Patientinnen in der mittleren Sekretionsphase deutlich exprimiert.

Schlussfolgerungen Es wurde die Hypothese aufgestellt, dass die starke Defizienz dieser Markermoleküle, die in Beziehung zur Angiogenese stehen, zu einer ungenügenden Ausbildung des Endometriums führt, das dann dünn bleibt. Eine unzureichende angiogenetische Entwicklung mag daher der Grund für eine endometriale Insuffizienz sein, die zur Infertilität führt. Weitergehende Studien sind nötig, um die Faktoren zu identifizieren, die zwischen der Steroidrezeptor-Aktivierung und der Expression dieser Markermoleküle regulierend wirken.

\section{Introduction}

The human endometrium is an important and specialized structure in the reproductive system. The main purpose of this type of tissue is to allow the embryo to implant, through a complex process of embryomaternal cross-talk. Over the last few decades, investigations of endometrial tissue during the implantation window have been carried out in order to identify the key receptors, cytokines, immunocompetent cells, and protein patterns involved in the implantation process. Marker molecules for endometrial receptivity are thought to be involved in endometrial function and particularly in the regulation of implantation. These markers include receptors such as $\alpha_{v} \beta_{3}$ integrin [1,2] and the leptin receptor (OB-Rb) $[3,4]$, and cytokines such as leukemia inhibitory factor (LIF) $[2,5]$ and vascular endothelial growth factor (VEGF) [6-8].

The relevance of these molecules for the implantation process has been investigated in animal models. In mice, it has been shown that LIF and OB-Rb are key molecules for fertility. An absence of LIF or OB-Rb leads to sterility in female mice $[9,10]$.

$\alpha_{v} \beta_{3}$ integrin is expressed in murine endometrium and blastocysts at the time of implantation. Carrying out a functional blockade of this integrin using specific neutralizing monoclonal antibodies against $\alpha_{v}$ or $\beta_{3}$ integrin subunits, Arg-Gly-Asp (RGD)-containing peptides, or the disintegrin echistatin was found to reduce the number of implantation sites in mice in comparison with controls receiving bovine serum albumin (BSA) [11]. An experimental mouse model of polycystic ovarian syndromes was found to have endometrium with an altered expression pattern of integrins such as $\alpha_{v}, \alpha_{4}, \beta_{1}$, and $\beta_{3}$ integrin in comparison with normal mice [12].

LIF induces a complex pattern of changes in endometrial epithelium, regulating murine embryo implantation by increasing expression of 256 genes during the first hour and with altered expression of 3987 genes after 3 hours. A distribution of key genes from 10 pathways has been confirmed, including VEGF and integrin receptors [13]. Gp130, the activating subunit of signal transducer and activator of transcription 3 (STAT3) is shared by all members of the interleukin-6 (IL-6) receptor family. Disruption of gp130 leads to a phenotype identical to the knockout for LIF [14].

Following the identification of marker molecules in the endometrium in fertile women and demonstration of their relevance for pregnancy in mice, interest has arisen in investigating their function in subfertile and infertile patients. A lack of endometrial $\alpha_{v} \beta_{3}$ integrin expression is associated with a poor prognosis for in vitro fertilization (IVF) [15]. It has been shown that women with stronger LIF and weak claudin-4 immunoreactivity during the window of implantation are more likely to become pregnant in comparison with women with lower levels of the protein - suggesting the importance of LIF in IVF [16].

LIF and gp130 influence the endometrial surface and regulate implantation at the human fetal-maternal interface [17]. DNA sequence changes have been found in the LIF genes of women with negative IVF outcome. LIF gene mutation may thus contribute to IVF failure [18].

Clinical observations have revealed an association with abnormally thin endometrium, detected on ultrasound, in a subgroup of subfertile patients. This thin endometrium is the only clinically apparent defect, and it may possibly suggest there is an endometrial factor that leads to infertility. An endometrial thickness of less than $7 \mathrm{~mm}$ is associated with a reduced pregnancy rate [1921]. Several groups have reported a significantly higher average value for endometrial thickness measurements in conception cycles in comparison with nonconception cycles [22,23]. Other investigators have compared endometrial volumes with implantation and pregnancy rates. Patients with an endometrial volume $<2 \mathrm{~mL}$ were found to have significantly lower $(\mathrm{p}<0.05)$ pregnancy and implantation rates in comparison with patients who had endometrial volumes of more than $2 \mathrm{~mL}$. No pregnancies were achieved with an endometrial volume $<1 \mathrm{~mL}$ [24]. It has been shown that abnormal endometrial biopsies are obtained more frequently in infertile (43\%) than in fertile women (9\%), in spite of adequate progesterone levels [25-28]. The thickness and pattern (e.g., trilinear) of the endometrium independently affect pregnancy outcomes. The combined endometrial thickness and pattern was not predictive for the outcome of IVF when the endometrial thickness was $<7 \mathrm{~mm}$ or $>14 \mathrm{~mm}$, while a triple-line pattern with a moderate endometrial thickness appeared to be associated with a good clinical outcome [29]. Priming of thin endometria with 150 IU human chorionic gonadotropin (hCG) during the proliferative phase in estrogen-substituted cycles is a highly promising form of treatment, as the thickness of the endometrium im- 
- Table 1 Antibodies used for immunohistochemistry.

\begin{tabular}{|l|l|l|l|}
\hline Antibody & Antigen & Dilution & Source \\
\hline Monoclonal (mouse) & & $1: 1000$ & $\begin{array}{l}\text { TaKaRa/British Biotechnology } \\
\text { Biermann Diagnostica, Germany }\end{array}$ \\
\hline BTC41 & $\beta_{3}$ integrin & $1: 50$ & Immunotech, Hamburg, Germany \\
\hline PR-10A9 & PR & $1: 50$ & Immunotech, Hamburg, Germany \\
\hline ER-1D5 & ER & $1: 60$ & Immunotech, Hamburg, Germany \\
\hline MIB-1 & Ki-67 & & \\
\hline Polyclonal antibodies (goat) & & $1: 100$ & R\&D Systems/Biermann Diagnostica, Germany \\
\hline Anti-human LIF & Human LIF & $1: 30$ & Santa Cruz Biotechnology, Heidelberg, Germany \\
\hline VEGF (A20) & VEGF (121,165,189) & \\
\hline ER, estrogen receptor; LIF, leukemia inhibitory factor; PR, progesterone receptor; VEGF, vascular endothelial growth factor.
\end{tabular}

proves and receptivity also becomes normalized [30]. There is a higher incidence of pregnancy in IVF patients who have a thick endometrium $\geq 10 \mathrm{~mm}$. According to Rinaldi et al., a thin endometrium is a prognostic indicator for female infertility in IVF patients [31]. Other research groups have not found that the endometrial thickness measured on ultrasound has any influence on pregnancy rates [32,33].

Taken together, these literature findings suggest that a thin and less developed endometrium may be associated with a reduced pregnancy rate in women. In the present study, marker molecules for endometrial receptivity that are involved in angiogenesis were therefore investigated in this specific subgroup of subfertile patients.

\section{Materials and Methods}

Endometrial biopsies were obtained from 11 subfertile women (mean age $32.90 \pm 3.03$ years) in the late proliferative and mid-secretory phase of one cycle, without any hormonal treatment. These patients, who had not achieved pregnancy within 1 year of clinical investigation in an infertility center, were defined as subfertile. Their clinical examinations had not revealed any pathological parameters, with the exception of an endometrial thickness of less than $7 \mathrm{~mm}$ during several stimulated cycles. The estradiol and progesterone values in peripheral blood in all of these patients had been within the normal physiological range throughout the ovulatory cycles. These patients represent a subgroup of individuals with idiopathic infertility, in whom disturbed endometrial development is the only detectable abnormality. It was hypothesized that they might have an endometrial factor leading to infertility.

36 endometrial biopsies of the late proliferative to the mid-secretory phase from women with normal menstrual cycles and confirmed fertility (mean age $40.4 \pm 4.7$ years) who were undergoing hysterectomy for benign uterine diseases were investigated and used as positive controls. None of the women with confirmed fertility had received any hormonal treatments during the previous 3 months.
The following parameters were taken into account for analyzing the menstrual phase in endometrial biopsies from fertile patients (controls) and subfertile patients:

1. clinical reports;

2. histological phase [34]; and

3. assessment of serum hormone concentrations (progesterone, estradiol, luteinizing hormone, and follicle-stimulating hormone) on the day of the biopsy procedure.

All of the biopsies from fertile and subfertile patients were investigated immunohistochemically to detect progesterone receptors and estrogen receptors, as well as the proliferation marker Ki-67. This combination of clinical, serological, and immunohistological parameters provided optimal assessment of the phase of the endometrial cycle.

Approval for the study was obtained from the ethics committee in the Medical Faculty of the University of Aachen.

\section{Immunohistochemistry}

Immunohistochemical analysis was carried out on paraffin sections $(4 \mu \mathrm{m})$ using a streptavidin-biotin peroxidase method, as described previously [3]. Endogenous peroxidase activity was blocked by incubation in $0.3 \%$ hydrogen peroxide for $30 \mathrm{~min}$. For the negative control, phosphate-buffered saline (PBS; Dulbecco) without $\mathrm{Ca}^{2+}$ and $\mathrm{Mg}^{2+} / 1.5 \%$ bovine serum albumin (BSA) replaced the primary antibody. In addition, rabbit immunoglobulin G (IgG; Dako, Hamburg, Germany), goat IgG (Dianova, Hamburg, Germany), normal mouse IgG (Dianova, Hamburg, Germany), and mouse IgG 1 kappa (Dako, Hamburg, Germany) were used as controls at the same concentration as the primary antibody. All primary antibodies ( $\vee$ Table 1 ) were applied overnight at $4{ }^{\circ} \mathrm{C}$. A Histostain-SP Kit (Zymed Laboratories Inc.) was used for monoclonal antibodies. Sections for polyclonal antibodies were incubated for 10 min at room temperature with normal swine serum (Dako; dilution $1: 20$ in $\mathrm{PBS} / 1.5 \% \mathrm{BSA}$ ) prior to incubation with the first antibody. Subsequently, the sections were incubated with a biotinylated second antibody (multi-link, swine, anti-goat, rabbit, mouse; Dako) for 30 min at room temperature. The dilution for the second antibody was $1: 150$ in PBS/1.5\% BSA. Incubation with 


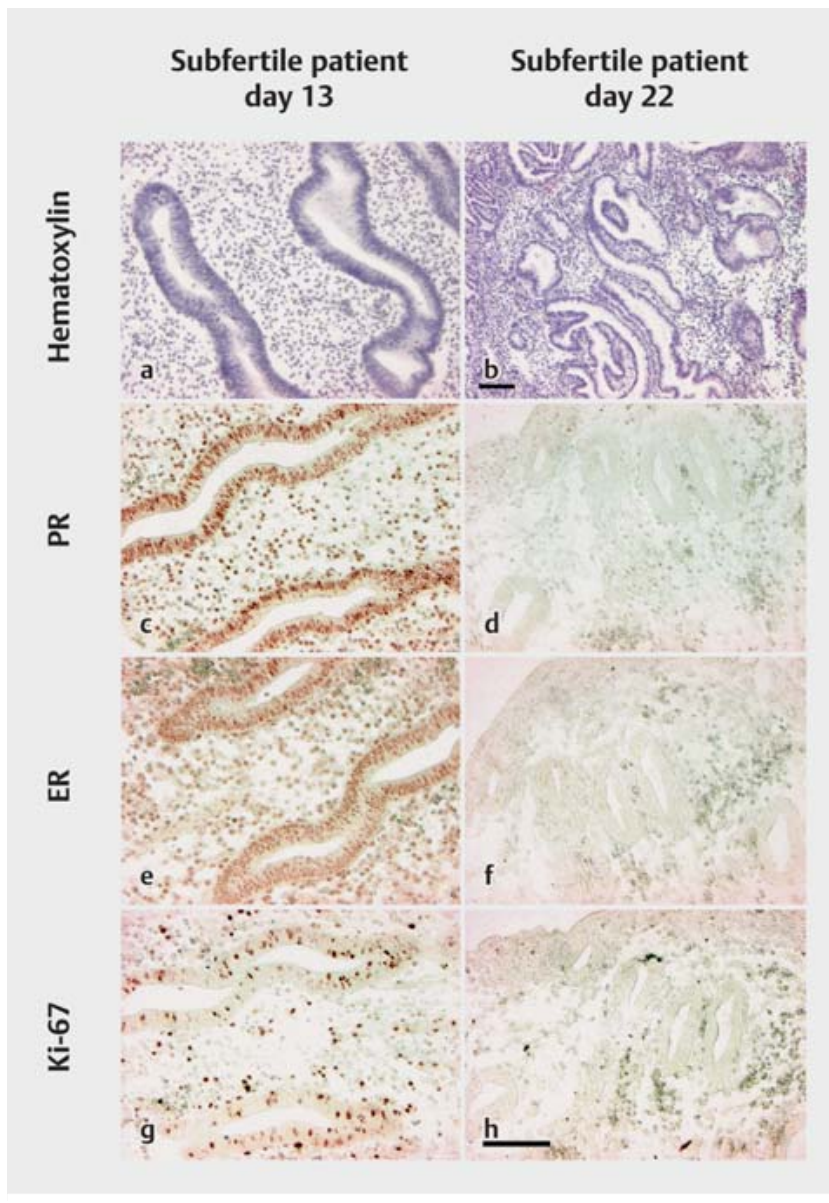

- Fig. 1 Endometrial biopsies from a subfertile patient taken during one menstrual cycle on days 13 and 22. Immunohistochemical stains on paraffin-embedded tissue sections. The scale bars in $b$ (only for $\mathbf{b}$ ) and $\mathbf{h}$ (for all other images) represent $100 \mu \mathrm{m}$. a Hematoxylin-stained biopsy from day 13 , showing proliferating glandular epithelium and stromal edema. b Hematoxylin-stained biopsy from day 22, showing transformed secretory glands. c Progesterone receptor (PR) on day 13 , showing strongly positive-stained nuclei in epithelial glands and stromal cells. $\mathbf{d}$ PR on day 22, showing negative glandular epithelium and scattered positive stromal cells. e Estrogen receptor (ER) on day 13, showing strongly positive-stained nuclei in epithelial glands and stromal cells. $f$ ER on day 22 , showing a few weakly positive nuclei in glandular epithelial cells and stromal cells. g Ki-67 on day 13 , showing positive-stained nuclei in glandular and stromal cells. h Ki-67 on day 22, showing scattered positive-stained nuclei in stromal cells and negative nuclei in glandular cells. streptavidin peroxidase conjugate (Dako) at a dilution of $1: 333$ in PBS/1.5\% BSA followed for $10 \mathrm{~min}$ at room temperature. After each incubation step, the tissues were washed three times with PBS. Visualization of the specific antigen was achieved with peroxidase catalyzing the substrate and converting the chromogen aminoethyl carbazole (AEC; Zymed Laboratories Inc., San Francisco, CA, USA) into a red deposit.

Pretreatment for antigen retrieval was used for antibodies against Ki-67, estrogen receptors, and progesterone receptors. The slides were heated in a sodium citrate buffer $(\mathrm{pH}$ 6.4) by mi- crowave $(4 \times 5 \mathrm{~min}, 600 \mathrm{~W})$ after rehydration. The antibodies against VEGF and $\beta_{3}$ integrin were pretreated with trypsin (Dako) for $15 \mathrm{~min}$ at room temperature. The antibody against LIF was used without any pretreatment of the tissue. The antibodies used are listed in $>$ Table 1.

\section{Results}

\section{Histology}

Histomorphological analysis of tissue from the subfertile patients showed endometrial transformation from the proliferative phase to the secretory phase. Development of the endometrial glands into the secretory phase was evident from comparison of the first and second biopsies. The glandular epithelium lost signs of pseudostratification and in three cases included a few glycogen vacuoles, indicating the influence of progesterone. The second biopsies corresponded to the end of the early to mid-secretory phase (days 18-21).

\section{Detection of steroid hormone receptors and proliferation markers}

The pattern of hormone receptor expression and its down-regulation was similar to the expression pattern in fertile patients. The proliferation marker Ki-67 was adequately expressed in the glandular epithelium and the stromal fibroblasts in the first biopsies. In the second biopsies, localized Ki-67 was only expressed in some stromal fibroblasts, similar to the expression seen in the secretory endometrial tissues of fertile patients ( $\bullet$ Fig. 1).

\section{Detection of marker molecules}

The glands in the first biopsies (from the late proliferative phase) were negative for $\beta_{3}$ integrin and LIF. The stromal fibroblasts showed only weakly positive localizations for these two marker molecules. The glands in all of the second biopsies (from the mid-secretory phase) were negative for $\beta_{3}$ integrin, and two biopsies showed weakly atypical staining for LIF in some glands.

The immunohistochemical results for VEGF in the first and second biopsies from the subfertile patients showed reduced or inadequate expression. In the second biopsies from the mid-secretory phase, VEGF was not expressed in seven cases, but weak staining in some glands was detected in four biopsies. Interestingly, typical staining for VEGF was not observed in the glands from the first biopsies. VEGF detection would have been expected in tissue from the proliferative phase, as reported previously by our group in endometrium from fertile women with normal menstrual cycles [8]. The stromal cells were weakly positive for VEGF ( $\bullet$ Fig. 2 ).

\section{Discussion}

In subfertile patients who have a thin endometrium $(<7 \mathrm{~mm})$ throughout the menstrual cycle, in the presence of normal steroid hormone receptor expression and regulation, endometrial biopsies were found to lack several marker molecules that are considered characteristic for endometrial receptivity. Histomorphological analysis showed that the endometrial tissue in the samples was in the mid-secretory phase or approaching the end of the 
early secretory phase. Surprisingly, it lacked or showed inadequate and weak expression of the relevant markers.

As a possible limitation of our study no quantification of the results has been performed. However, the lack of marker molecules in the subfertile patients was very obvious and the pattern of hormone receptor expression and its down-regulation was completely similar between fertile and subfertile women.

An earlier investigation carried out by our group on the expression of the leptin receptor in endometrial tissue showed similar findings [3]. Biopsies taken during the proliferative phase were deficient for vascular endothelial growth factor (VEGF) and leptin receptor, although these markers are expressed in normal proliferative endometrium in fertile women. The endometrial maturation defect apparently already starts in the proliferative phase and becomes clearly evident during the secretory phase. There is evidence that a certain network of interactions exists among the different marker molecules. The leptin receptor is able to influence the expression of VEGF and vascular endothelial growth factor receptor (VEGF-R) [35-40], $\beta_{3}$ integrin [41], and leukemia inhibitory factor (LIF) [42]. LIF has a positive influence on VEGF $[13,43]$ and integrin expression $[17,44,45]$. VEGF in turn is able to influence integrin expression [46]. The integrin $\alpha_{v} \beta_{3}$ again is involved in the activation of VEGF-R2 after binding of the L1 cell adhesion molecule (L1/g6), a ligand of this integrin receptor [47] ( Fig. 3) $[13,17,36-48]$.

\section{VEGF}

The thin endometrium correlates with a lack of the molecules that are involved in angiogenesis. VEGF was only detectable in a few endometrial glands during the secretory phase in subfertile patients. However, the endometrium in patients with proven fertility (the control group) showed strong regular staining of VEGF during this phase. The lack of VEGF may possibly lead to inadequate blood vessel growth in patients with thin endometrium. VEGF is able to up-regulate the expression of von Willebrand factor (vWF) mRNA and protein in cultured endothelial cells $[49,50]$. The number of vessels was not reduced, as revealed by detection of vessels with vWF (data not shown), but their growth may be retarded, in turn inhibiting the transformation process in the endometrium.

\section{LIF}

LIF plays a functional role in angiogenesis. In cardiac myocytes, LIF is able to activate VEGF expression via signals through gp130/ STAT3. Intravenous administration of LIF has been shown to augment the expression of VEGF mRNA in murine heart tissue. Myocardial tissue from transgenic mice overexpressing dominantnegative STAT3 showed reduced expression of VEGF mRNA, which was not induced after LIF stimulation. Stimulation of rat cardiac myocytes in a cell culture system with LIF resulted in a rapid increase in VEGF mRNA and protein expression [43, 51]. LIF may also play a critical role in controlling angiogenesis in the placental villi, since human fetal endothelial cells express leukemia inhibitory factor receptor (LIF-R), and mice that lack a functional LIF receptor gene show altered vascular development in the placenta [52]. Inhibition of LIF during mid-gestation impairs trophoblast invasion and spiral artery remodeling during pregnancy in mice [53].

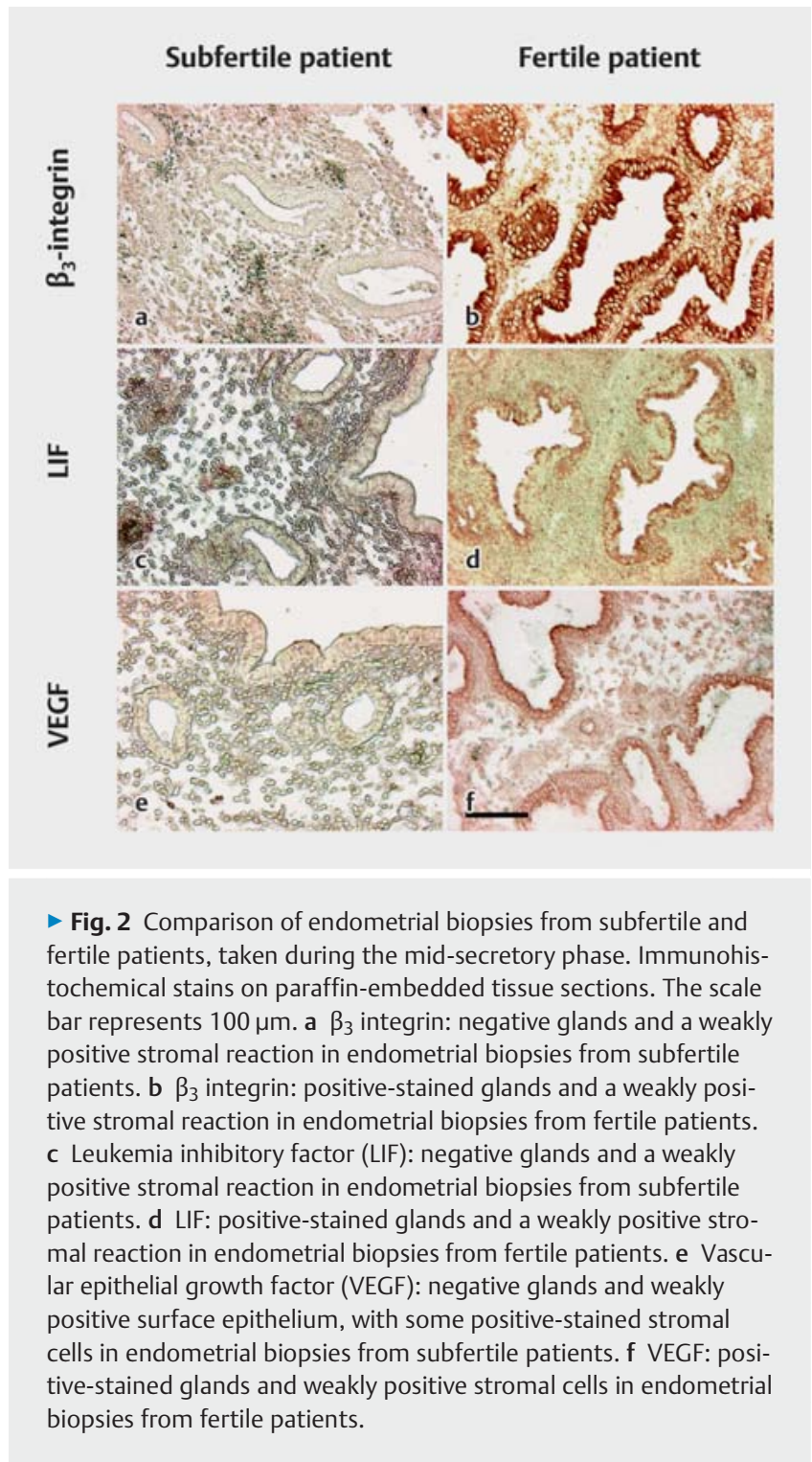

Blocking endogenous LIF during placental development in mice leads to abnormal placentation and pregnancy loss [54]. There is thus abundant evidence that LIF may be involved in angiogenesis in the endometrium and placenta. LIF may possibly also affect VEGF expression in the human endometrium.

Evidence from animal studies [9] has shown that LIF is essential for blastocyst implantation. The absence of LIF observed in glandular epithelial cells in endometrial biopsies obtained from subfertile patients may also contribute to subfertility. Hambartsoumian [55] reported differences between fertile and infertile women in relation to LIF secretion in endometrial explant cultures. In fertile women, endometrial LIF secretion was 2.2 times higher in the secretory phase than in the proliferative phase. Infertile women were not found to have this elevation of LIF production during the secretory phase [56]. Heterozygous LIF gene mutations have also been detected in infertile women (in three of 74 patients) [57]. The authors considered that these mutations might be responsible for the reduced LIF protein production described by 


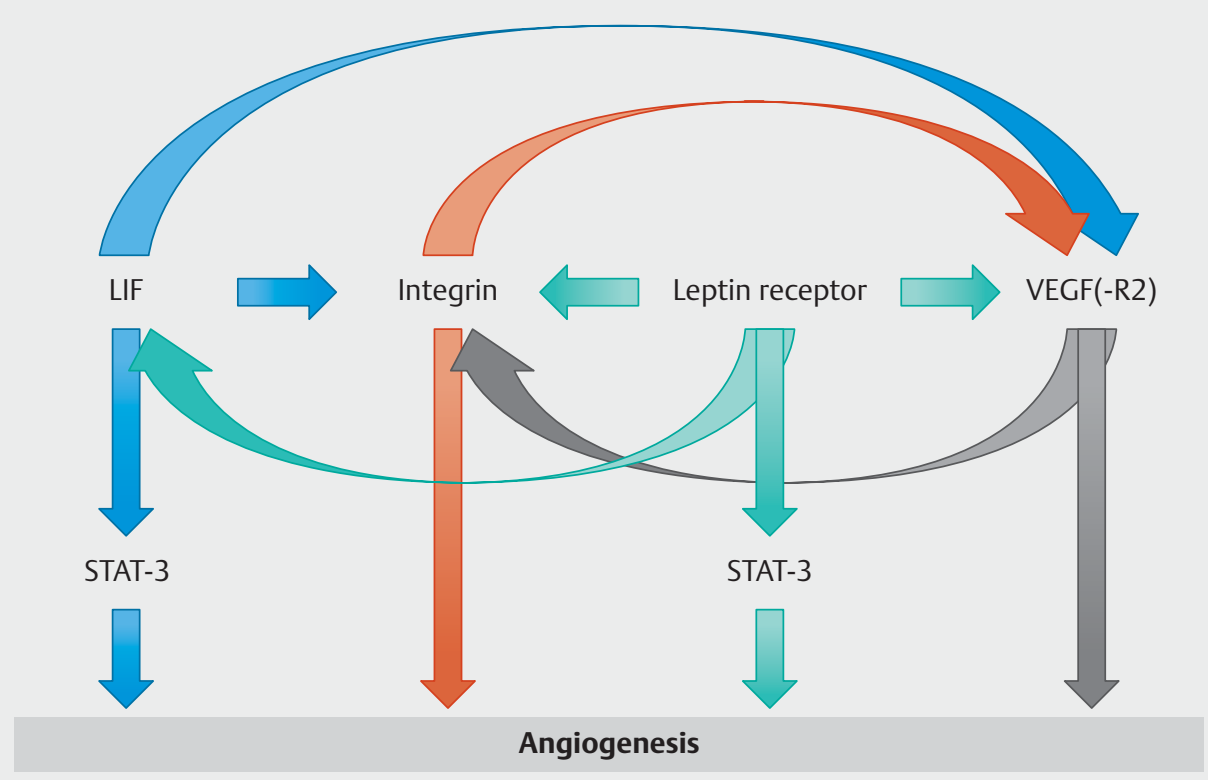

- Fig. 3 Interactions among marker molecules that influence angiogenesis. The leptin receptor influences vascular epithelial growth factor (VEGF) and vascular epithelial growth factor receptor-1 (VEGF-R1) [36-40]; $\beta_{3}$ integrin [41]; and leukemia inhibitory factor (LIF) [42]. LIF influences VEGF $[13,43]$ and integrin $[17,44,45]$. VEGF influences integrin $[46,48]$. Integrin influences VEGF-R2 [47].

Laird et al. [58] and Hambartsoumian [55]. A study including 25 women with unexplained infertility found that they had a significantly reduced level of LIF mRNA. LIF was not detectable in $88 \%$ of the infertile women while it was fairly detectable in $12 \%$ of them. Significantly fewer LIF and gp130 molecules were found in uterine flushing in infertile women in comparison with normally fertile women. Tawfeek et al. suggested that expression of LIF mRNA in the endometrium could be used as a molecular marker for unexplained infertility [59].

Treatment with recombinant human LIF (rhLIF) has been investigated in preclinical and clinical trials as a method of improving endometrial receptivity in patients with recurrent implantation failure (RIF). It was suggested that compensating for low levels of endometrial LIF expression might have a positive effect on the outcome of IVF in women with recurrent implantation failure. Unfortunately, rhLIF administration during the secretory phase after embryo transfer failed to improve implantation rates in women with recurrent implantation failure [60]. It is possible that the endometrium had not shifted into the secretory phase sufficiently; rhLIF administration alone is thus not able to provide the wide range of factors present in a receptive endometrium.

\section{$\alpha_{v} \beta_{3}$ integrin}

Several studies have reported that $\alpha_{v} \beta_{3}$ integrin is related to angiogenesis and VEGF. Expression of $\alpha_{v} \beta_{3}$ integrin in endothelial cells is induced by VEGF in vitro [46]. Both $\alpha_{v} \beta_{3}$ integrin and VEGF up-regulation have also been shown to prevent endothelial cell apoptosis in vitro $[48,61]$. The lack of $\alpha_{v} \beta_{3}$ seen in the endometrium of the subfertile patients included in the present study might therefore be due to a VEGF deficiency. $\alpha_{v} \beta_{3}$ integrin is able to pro- mote endothelial cell migration in a calcium-dependent manner [62]. It has been demonstrated that this receptor is involved in vacuolation and lumen formation in human umbilical vein endothelial cells in a fibrin matrix [63]. The receptor is expressed in blood vessels in human wound granulation tissue, but not in normal skin [64]. Integrin $\alpha_{v} \beta_{3}$ antagonists have been reported to promote tumor regression by inducing apoptosis of angiogenic blood vessels in a chick chorioallantoic membrane [64]. Exposure of human endothelial cells to tumor necrosis factor (TNF) and interferon gamma (IFN- $\mathrm{y}$ ) results in reduced activation of $\alpha_{\mathrm{v}} \beta_{3}$ integrin and leads to decreased $\alpha_{v} \beta_{3}$-dependent endothelial cell adhesion and survival. Preclinical studies have shown that RGD peptidomimetics and a monoclonal antibody to $\alpha_{v} \beta_{3}$ integrin can inhibit tumor growth by blocking tumor-induced angiogenesis [65]. $\alpha_{v} \beta_{3}$ integrin in particular has an important impact on the regulation of normal and tumor cell migration, as well as on angiogenesis and tumor metastasis [66]. Coughlan et al. did not detect any significant differences in $\alpha_{v} \beta_{3}$ integrin expression in any compartment of the endometrium between women with recurrent implantation failure (RIF) and control women. It is possible that only a few patients in the study group had the endometrial defect lacking $\alpha_{v} \beta_{3}$ integrin that leads to infertility. Coughlan et al. did not focus on patients with suspected endometrial defects, and the endometrial tissue studied may therefore not have had any significant differences in comparison with the control group [67].

Data from in vivo and in vitro investigations show that $\alpha_{v} \beta_{3}$ integrin is able to regulate angiogenesis in human and animal tissues. Its expression may therefore also play an important angiogenic role in the human endometrium. 


\section{Leptin receptor}

The leptin receptor is involved in angiogenesis [68, 69]. Immunoreactivity for OB-R, VEGF, and matrix metalloproteinase (MMP) is up-regulated in atherosclerotic plaque, predominantly in the endothelial lining of the intimal neovessel [70]. Leptin induces endothelial cell proliferation and expression of matrix metalloproteinases in vivo and in vitro. Immunohistological analysis of leptintreated rat cornea showed a definite increase in the expression of OB-R, MMPs, and TIMPs, and also of VEGF receptor-1 (VEGF-R1). Leptin induced proliferation of the human umbilical vein endothelial cells (HUVECs) and elevation of MMP-2, MMP-9, TIMP-1 and TIMP-2 expression in a dose-dependent manner [37]. These results once again demonstrate the involvement of leptin in angiogenesis and further support the theory that a lack of leptin receptor may lead to inadequate angiogenesis in the endometrium as well [36].

Leptin induces proliferation and angiogenic differentiation of endothelial cells, up-regulates VEGF/VEGF-R2, and transactivates VEGF-R2 independently of VEGF. Leptin induces angiogenic factors such as IL-1 and Notch, which can increase VEGF. Its pro-angiogenic actions have been summarized in review articles by Gonzalez-Perez et al. [38], Krikun [39], and Adya et al. [40]. Reduced expression of anti-inflammatory and angiogenic cytokines has been observed in women with idiopathic recurrent spontaneous miscarriage (IRSM). Markers of endometrial receptivity were poorly expressed in women with IRSM [71].

As we have shown previously [3] the leptin receptor (long splice variant) is absent or inadequately expressed in the endometrium in subfertile patients who have an abnormally thin endometrium.

\section{Conclusions}

Leukemia inhibitory factor (LIF), vascular endothelial growth factor (VEGF), and $\beta_{3}$ integrin, which are marker molecules for endometrial receptivity, were found to be inadequately expressed or completely absent in the endometrial tissue samples in this specific group of subfertile patients with suspected endometrial deficiency. Although these markers were initially identified and investigated independently of each other, they have a positive influence on one other and are involved in angiogenesis ( $>$ Fig. 3 ). The endometrial deficiency appears already to commence during the proliferative phase, as shown by a lack of VEGF and leptin receptor [8]. Angiogenic defects may thus lead to insufficient secretory transformation, resulting in a thin endometrium that is consequently incapable of providing a mature environment for the implanting embryo. The endometrial deficiency observed is not merely due to a phase delay with late maturation.

In these patients, the endometrium is unable to reach a fully receptive implantation phase in most cycles, although the patients ovulate and have normal serum hormone levels, followed by normal expression and down-regulation of steroid hormone receptors. The fact that the patients become pregnant in a few cases, but never deliver, suggested that the endometrial problem is a functional one, with different developmental and maturation grades in each endometrial cycle.
The deficiency of the marker molecules concerned strongly supports the hypothesis that there is disturbed angiogenesis, leading to insufficient secretory transformation and resulting in a thin endometrium that causes a reduced implantation rate in this group of subfertile patients. It may be suspected that there must be a regulatory defect after the activation of steroid hormone receptors that precedes the translation of these marker molecules. Further research is needed to identify the underlying regulatory mechanisms involved in this endometrial maturation deficiency.

\section{Acknowledgements}

We are grateful to the women who agreed to participate in research for this study.

\section{Conflict of Interest}

The authors report that they have no conflicts of interest. The authors alone are responsible for the content and writing of this paper.

\section{References}

[1] Lessey BA, Damjanovich L, Coutifaris C et al. Integrin adhesion molecules in the human endometrium. Correlation with the normal and abnormal menstrual cycle. J Clin Invest 1992; 90: 188-195

[2] Classen-Linke I, Alfer J, Hey S et al. Marker molecules of human endometrial differentiation can be hormonally regulated under in-vitro conditions as in-vivo. Hum Reprod Update 1998; 4: 539-549

[3] Alfer J, Müller-Schöttle F, Classen-Linke I et al. The endometrium as a novel target for leptin: differences in fertility and subfertility. Mol Hum Reprod 2000; 6: 595-601

[4] Kitawaki J, Koshiba $\mathrm{H}$, Ishihara $\mathrm{H}$ et al. Expression of leptin receptor in human endometrium and fluctuation during the menstrual cycle. J Clin Endocrinol Metab 2000; 85: 1946-1950

[5] Kojima K, Kanzaki H, Iwai M et al. Expression of leukemia inhibitory factor in human endometrium and placenta. Biol Reprod 1994; 50: 882887

[6] Shifren JL, Tseng JF, Zaloudek C] et al. Ovarian steroid regulation of vascular endothelial growth factor in the human endometrium: implications for angiogenesis during the menstrual cycle and in the pathogenesis of endometriosis. J Clin Endocrinol Metab 1996; 81: 3112-3118

[7] Gargett CE, Lederman FL, Lau TM et al. Lack of correlation between vascular endothelial growth factor production and endothelial cell proliferation in the human endometrium. Hum Reprod 1999; 14: 2080-2088

[8] Classen-Linke I, Alfer J, Krusche CA et al. Progestins, progesterone receptor modulators, and progesterone antagonists change VEGF release of endometrial cells in culture. Steroids 2000; 65: 763-771

[9] Stewart CL, Kaspar P, Brunet L] et al. Blastocyst implantation depends on maternal expression of leukaemia inhibitory factor. Nature 1992; 359: 76-79

[10] Chehab FF, Lim ME, Lu R. Correction of the sterility defect in homozygous obese female mice by treatment with the human recombinant leptin. Nat Genet 1996; 12: 318-320

[11] Illera MJ, Cullinan E, Gui Y et al. Blockade of the alpha(v)beta(3) integrin adversely affects implantation in the mouse. Biol Reprod 2000; 62: $1285-1290$

[12] Peyghambari F, Fayazi M, Amanpour $S$ et al. Assessment of $\alpha 4$, $\alpha v, \beta 1$ and $\beta 3$ integrins expression throughout the implantation window phase in endometrium of a mouse model of polycystic ovarian syndromes. Iran J Reprod Med 2014; 12: 687-694 
[13] Rosario GX, Hondo E, Jeong JW et al. The LIF-mediated molecular signature regulating murine embryo implantation. Biol Reprod 2014; 91: 66

[14] Akira S, Yoshida K, Tanaka T et al. Targeted disruption of the IL-6 related genes: gp130 and NF-IL-6. Immunol Rev 1995; 148: 221-253

[15] Miller PB, Parnell BA, Bushnell G et al. Endometrial receptivity defects during IVF cycles with and without letrozole. Hum Reprod 2012; 27: 881-888

[16] Serafini PC, Silva ID, Smith GD et al. Endometrial claudin-4 and leukemia inhibitory factor are associated with assisted reproduction outcome. Reprod Biol Endocrinol 2009; 7: 30

[17] Dimitriadis E, Nie G, Hannan NJ et al. Local regulation of implantation at the human fetal-maternal interface. Int J Dev Biol 2010; 54: 313-322

[18] Sabry D, Nouh O, Marzouk S et al. Pilot study on molecular quantitation and sequencing of endometrial cytokines gene expression and their effect on the outcome of in vitro fertilization (IVF) cycle. J Adv Res 2014; 5: 595-600

[19] Alam V, Bernardini L, Gonzales ] et al. A prospective study of echographic endometrial characteristics and pregnancy rates during hormonal replacement cycles. J Assist Reprod Genet 1993; 10: 215-219

[20] Abdalla HI, Brooks AA, Johnson MR et al. Endometrial thickness: a predictor of implantation in ovum recipients? Hum Reprod 1994; 9: 363-365

[21] Wu Y, Gao X, Lu X et al. Endometrial thickness affects the outcome of in vitro fertilization and embryo transfer in normal responders after $\mathrm{GnRH}$ antagonist administration. Reprod Biol Endocrinol 2014; 12: 96

[22] Turnbull LW, Lesny P, Killick SR. Assessment of uterine receptivity prior to embryo transfer: a review of currently available imaging modalities. Hum Reprod Update 1995; 1: 505-514

[23] Friedler S, Schenker JG, Herman A et al. The role of ultrasonography in the evaluation of endometrial receptivity following assisted reproductive treatments: a critical review. Hum Reprod Update 1996; 2: 323-335

[24] Raga F, Bonilla-Musoles F, Casañ EM et al. Assessment of endometrial volume by three-dimensional ultrasound prior to embryo transfer: clues to endometrial receptivity. Hum Reprod 1999; 14: 2851-2854

[25] Batista MC, Cartledge TP, Zellmer AW et al. A prospective controlled study of luteal and endometrial abnormalities in an infertile population. Fertil Steril 1996; 65: 495-502

[26] Graham RA, Seif MW, Aplin JD et al. An endometrial factor in unexplained infertility. BMJ 1990; 300: 1428-1431

[27] Li TC, Dockery P, Rogers AW et al. A quantitative study of endometrial development in the luteal phase: comparison between women with unexplained infertility and normal fertility. Br J Obstet Gynaecol 1990; 97: $576-582$

[28] Klentzeris LD, Li TC, Dockery P et al. The endometrial biopsy as a predictive factor of pregnancy rate in women with unexplained infertility. Eur J Obstet Gynecol Reprod Biol 1992; 45: 119-124

[29] Zhao J, Zhang Q, Li Y. The effect of endometrial thickness and pattern measured by ultrasonography on pregnancy outcomes during IVF-ET cycles. Reprod Biol Endocrinol 2012; 10: 100

[30] Papanikolaou EG, Kyrou D, Zervakakou G et al. Follicular HCG endometrium priming for IVF patients experiencing resisting thin endometrium. A proof of concept study. J Assist Reprod Genet 2013; 30: 1341-1345

[31] Rinaldi L, Lisi F, Floccari A et al. Endometrial thickness as a predictor of pregnancy after in-vitro fertilization but not after intracytoplasmic sperm injection. Hum Reprod 1996; 11: 1538-1541

[32] Yuval Y, Lipitz S, Dor J et al. The relationships between endometrial thickness, and blood flow and pregnancy rates in in-vitro fertilization. Hum Reprod 1999; 14: 1067-1071

[33] De Geyter C, Schmitter M, De Geyter M et al. Prospective evaluation of the ultrasound appearance of the endometrium in a cohort of 1,186 infertile women. Fertil Steril 2000; 73: 106-113

[34] Noyes RW. The underdeveloped secretory endometrium. Am J Obstet Gynecol 1959; 77: 929-945
[35] Klauber N, Rohan RM, Flynn E et al. Critical components of the female reproductive pathway are suppressed by the angiogenesis inhibitor AGM-1470. Nat Med 1997; 3: 443-446

[36] Cascio S, Ferla R, D’Andrea A et al. Expression of angiogenic regulators, VEGF and leptin, is regulated by the EGF/PI3K/STAT3 pathway in colorectal cancer cells. J Cell Physiol 2009; 221: 189-194

[37] Park HY, Kwon HM, Lim HJ et al. Potential role of leptin in angiogenesis: leptin induces endothelial cell proliferation and expression of matrix metalloproteinases in vivo and in vitro. Exp Mol Med 2001; 33: 95-102

[38] Gonzalez-Perez RR, Lanier V, Newman G. Leptin's pro-angiogenic signature in breast cancer. Cancers (Basel) 2013; 5: 1140-1162

[39] Krikun G. Endometriosis, angiogenesis and tissue factor. Scientifica (Cairo) 2012; 2012: 306830

[40] Adya R, Tan BK, Randeva HS. Differential effects of leptin and adiponectin in endothelial angiogenesis. J Diabetes Res 2015; 2015: 648239

[41] Gonzalez RR, Leavis P. Leptin upregulates beta3-integrin expression and interleukin-1beta, upregulates leptin and leptin receptor expression in human endometrial epithelial cell cultures. Endocrine 2001; 16: 21-28

[42] Carino C, Olawaiye AB, Cherfils S et al. Leptin regulation of proangiogenic molecules in benign and cancerous endometrial cells. Int J Cancer 2008; 123: 2782-2790

[43] Funamoto M, Fujio Y, Kunisada K et al. Signal transducer and activator of transcription 3 is required for glycoprotein 130-mediated induction of vascular endothelial growth factor in cardiac myocytes. J Biol Chem 2000; 275: 10561-10566

[44] Kim EY, Choi HJ, Chung TW et al. Water-extracted Perilla frutescens increases endometrial receptivity though leukemia inhibitory factor-dependent expression of integrins. J Pharmacol Sci 2016; 131: 259-266

[45] Chung TW, Park M], Kim HS et al. Integrin $\alpha \mathrm{V} \beta 3$ and $\alpha \mathrm{V} \beta 5$ are required for leukemia inhibitory factor-mediated the adhesion of trophoblast cells to the endometrial cells. Biochem Biophys Res Commun 2016; 469: 936-940

[46] Senger DR, Ledbetter SR, Claffey KP et al. Stimulation of endothelial cell migration by vascular permeability factor/vascular endothelial growth factor through cooperative mechanisms involving the alphavbeta3 integrin, osteopontin, and thrombin. Am J Pathol 1996; 149: 293-305

[47] Hall H, Hubbell JA. Matrix-bound sixth Ig-like domain of cell adhesion molecule L1 acts as an angiogenic factor by ligating alphavbeta3-integrin and activating VEGF-R2. Microvasc Res 2004; 68: 169-178

[48] Spyridopoulos I, Brogi E, Kearney M et al. Vascular endothelial growth factor inhibits endothelial cell apoptosis induced by tumor necrosis factor-alpha: balance between growth and death signals. J Mol Cell Cardiol 1997; 29: 1321-1330

[49] Zanetta L, Marcus SG, Vasile J et al. Expression of Von Willebrand factor, an endothelial cell marker, is up-regulated by angiogenesis factors: a potential method for objective assessment of tumor angiogenesis. Int J Cancer 2000; 85: 281-288

[50] McLaren M, Elhadd TA, Greene SA et al. Elevated plasma vascular endothelial cell growth factor and thrombomodulin in juvenile diabetic patients. Clin Appl Thromb 1999; 5: 21-24

[51] Pourtau ], Mirshahi F, Li H et al. Cyclooxygenase-2 activity is necessary for the angiogenic properties of oncostatin M. FEBS Lett 1999; 459: $453-457$

[52] Ware CB, Horowitz MC, Renshaw BR et al. Targeted disruption of the low-affinity leukemia inhibitory factor receptor gene causes placental, skeletal, neural and metabolic defects and results in perinatal death. Development 1995; 121: 1283-1299

[53] Winship A, Correia J, Zhang JG et al. Leukemia inhibitory factor (LIF) inhibition during mid-gestation impairs trophoblast invasion and spiral artery remodelling during pregnancy in mice. PLoS One 2015; 10: e0129110 
[54] Winship A, Correia J, Krishnan T et al. Blocking endogenous leukemia inhibitory factor during placental development in mice leads to abnormal placentation and pregnancy loss. Sci Rep 2015; 5: 13237

[55] Hambartsoumian E. Endometrial leukemia inhibitory factor (LIF) as a possible cause of unexplained infertility and multiple failures of implantation. Am J Reprod Immunol 1998; 39: 137-143

[56] Piccinni MP, Beloni L, Livi C et al. Defective production of both leukemia inhibitory factor and type $2 \mathrm{~T}$-helper cytokines by decidual T cells in unexplained recurrent abortions. Nat Med 1998; 4: 1020-1024

[57] Giess R, Tanasescu I, Steck T et al. Leukaemia inhibitory factor gene mutations in infertile women. Mol Hum Reprod 1999; 5: 581-586

[58] Laird SM, Tuckerman EM, Dalton CF et al. The production of leukaemia inhibitory factor by human endometrium: presence in uterine flushings and production by cells in culture. Hum Reprod 1997; 12: 569-574

[59] Tawfeek MA, Eid MA, Hasan AM et al. Assessment of leukemia inhibitory factor and glycoprotein 130 expression in endometrium and uterine flushing: a possible diagnostic tool for impaired fertility. BMC Womens Health 2012; 12: 10

[60] Brinsden PR, Alam V, de Moustier B et al. Recombinant human leukemia inhibitory factor does not improve implantation and pregnancy outcomes after assisted reproductive techniques in women with recurrent unexplained implantation failure. Fertil Steril 2009; 91: 1445-1447

[61] Strömblad S, Becker JC, Yebra M et al. Suppression of p 53 activity and p21WAF1/CIP1 expression by vascular cell integrin alphaVbeta3 during angiogenesis. J Clin Invest 1996; 98: 426-433

[62] Leavesley DI, Schwartz MA, Rosenfeld M et al. Integrin beta 1- and beta 3-mediated endothelial cell migration is triggered through distinct signaling mechanisms. J Cell Biol 1993; 121: 163-170
[63] Bayless KJ, Salazar R, Davis GE. RGD-dependent vacuolation and lumen formation observed during endothelial cell morphogenesis in three-dimensional fibrin matrices involves the alpha(v)beta(3) and alpha(5)beta (1) integrins. Am J Pathol 2000; 156: 1673-1683

[64] Brooks PC, Clark RA, Cheresh DA. Requirement of vascular integrin alpha $v$ beta 3 for angiogenesis. Science 1994; 264: 569-571

[65] Westlin WF. Integrins as targets of angiogenesis inhibition. Cancer J 2001; 7 (Suppl. 3): S139-S143

[66] Liu Z, Yu L, Wang $X$ et al. Integrin ( $\alpha v \beta 3$ ) Targeted RGD peptide based probe for cancer optical imaging. Curr Protein Pept Sci 2016; 17: 570581

[67] Coughlan C, Sinagra M, Ledger W et al. Endometrial integrin expression in women with recurrent implantation failure after in vitro fertilization and its relationship to pregnancy outcome. Fertil Steril 2013; 100: 825830

[68] Sierra-Honigmann MR, Nath AK, Murakami C et al. Biological action of leptin as an angiogenic factor. Science 1998; 281: 1683-1686

[69] Bouloumié A, Drexler HC, Lafontan M et al. Leptin, the product of Ob gene, promotes angiogenesis. Circ Res 1998; 83: 1059-1066

[70] Kang SM, Kwon HM, Hong BK et al. Expression of leptin receptor (Ob-R) in human atherosclerotic lesions: potential role in intimal neovascularization. Yonsei Med J 2000; 41: 68-75

[71] Banerjee P, Jana SK, Pasricha P et al. Proinflammatory cytokines induced altered expression of cyclooxygenase-2 gene results in unreceptive endometrium in women with idiopathic recurrent spontaneous miscarriage. Fertil Steril 2013; 99: 179-187 